\title{
Quality of Financial Reporting of the Enterprise: Evaluation Methodology
}

\author{
By Nataliia Pravdiuk ${ }^{1}$, Valerii Bondarenko ${ }^{2}$, Vitalii Pokynchereda ${ }^{3}$, Olga Timchenko ${ }^{4}$
}

\begin{abstract}
The article substantiates the necessity of carrying out the assessment of the quality of financial reporting of the enterprise with the purpose of inserting the level of its information filling to the needs of users and increasing their confidence in the institute of accounting. Proceeding from it theoretical and methodological positions of estimation of quality of the financial reporting on the basis of use of the theory of qualimetry are developed. The proposed model covers three consecutive stages, which provide for the description of the process of assessing the quality of financial reporting, the formation of a system of indicators for assessing the quality of financial reporting and determining the scale of their assessment, the quantitative assessment of qualitative properties of financial reporting, the analysis of the results of assessing the quality of financial reporting and management decisions. It is grounded that practical application of the developed method of assessment of financial reporting quality in contrast to the existing methods allows the development of separate models of assessment of financial reporting quality taking into account the needs of specific groups of users of accounting information and in accordance with the priority of qualitative properties of financial reporting defined by them.
\end{abstract}

Keywords: quality of financial reporting; quality of accounting information; integral indicator of quality of financial reporting; qualified model of assessment of quality of financial reporting

\section{Introduction}

In today's business environment, accounting information is becoming a key factor, without which any prospects for economic growth are leveled out. However, as economic relations become more globalized and the quality of accounting information becomes more demanding, the proper implementation of the information function of accounting becomes much more complicated. Today, information as a product of accounting must reflect more complex, global and rapidly changing business processes, ensuring the ability of managers to respond quickly to economic challenges. This necessitates the development of such principles for the formation of accounting information, ensuring an appropriate level of quality and meeting the needs of external and internal users.

The need to assess the quality of accounting information is justified by the emergence in the early twentieth century of a significant number of corporate scandals related to the 
implementation of manipulations with financial reporting, which led to the reform of mechanisms and procedures for auditing financial statements (Sarbanes-Oxley Act 2002). Thus, the quality of financial reporting is the main problem of further development of the accounting system, the successful solution of which determines the reputation of accounting as the main source of information for making managerial decisions. Improvement of quality of the accounting information promotes economy of transactional expenses of the enterprise, increase of efficiency of administrative process and success of functioning of capital markets.

\section{Literature Review}

Issues related to the study of the essence and place of accounting information in the system of information support of management, as well as methodological approaches to assessing the quality of financial reporting is the subject of scientific research of many economists. In particular, A. Picot, studying the role of information in ensuring the success of the enterprise, including it in the composition of production factors along with labor, land and capital (Picot 1989). Theoretical and practical aspects of accounting information quality management are covered in scientific works of K. Panitz, A. Sauer, S. Waschkowitz, C. Offenhammer, M. Wiegard. Scientists note that the quality of accounting information is related to the compliance or noncompliance with certain target criteria related to temporary (e.g., timeliness of information) and expenditure aspects (appropriateness of costs of information quality assessment) (Panitz et al. 2010; Offenhammer \& Wiegard 2017). Scientists (Call et al. 2017) study the relationship between the level of professional training of employees and the quality of financial reporting. In particular, it has been established that at the enterprises with a high level of employees' qualification, financial statements contain information with better qualitative characteristics, adhere to internal control procedures, and management forecasts are more relevant, accurate and timely.

The introduction and wide application of international financial reporting standards, which determine the qualitative characteristics of accounting information presented in financial statements, was of great importance for improving the quality of financial reporting (Paucan 2015). Empirical studies show that the most important qualitative characteristics of accounting information for managers of enterprises are relevance, reliability, timeliness, comparability and comprehensibility (Nobesa \& Stadlerb 2015). On the basis of this, scientists have developed various methods of assessing the quality of financial reporting, allowing to assess the quality of financial reporting based on the above characteristics of accounting information (Beest et al. 2009; Al-Dmour et al. 2018; Kalyani et al. 2019). These models differ in terms of both the content of their underlying assumptions and the form of implementation and the set of qualitative characteristics to be assessed. The lack of a common position among accounting scholars on the formation of a methodology for assessing the quality of financial reporting is a consequence of different understanding of the reasons for the need for a qualitative approach in accounting and the essence of the concept of quality of accounting information and financial reporting (Plakhtiy \& Pravdiuk 2017).

The majority of the developed methods for assessing the quality of financial reporting are expert, which provide for consistent implementation of the following stages: structuring 
the qualitative characteristics of accounting information, determining the degree of compliance of its qualitative characteristics with reference indicators, calculating the basic indicator of quality of accounting information, ranking the qualitative characteristics of information by users and calculating the integrated indicator of quality of accounting information (Pravdiuk \& Pravdiuk, 2016; Pokynchereda at al. 2017; Plakhtiy 2018; Pravdiuk et al. 2019).

Thus, despite the detailed development of a multifaceted problem of assessing the quality of financial reporting, at present there is no generally accepted system of indicators to assess the quality of accounting information, creates practical obstacles to determine its value in the process of development and management decisions.

The research goal is to develop theoretical, methodological and practical aspects of assessing the quality of the financial reporting of the enterprise in accordance with the information needs of users of accounting information.

\section{Results}

According to the "Reporting Survey" conducted by the audit firm "PricewaterhouseCoopers", 65\% of surveyed managers of enterprises noted that the highest priority in the preparation of financial statements is the quality of the information presented in it, while the optimization of costs and time to generalize and obtain reporting indicators is important for 29 and $6 \%$ of respondents, respectively. High requirements to the quality of financial reporting are the result of the growing importance of public image of companies and constant monitoring of their development by investors. At the same time, 25 and $44 \%$ of respondents respectively highly appreciate the quality of information provided in the financial statements of their companies, and $85 \%$ of companies plan to take further measures to improve the quality of financial reporting. Such measures for the majority of enterprises are further standardization of accounting, implementation of integrated information systems, automation of internal control, harmonization of external and internal reporting, etc. (Figure 1).

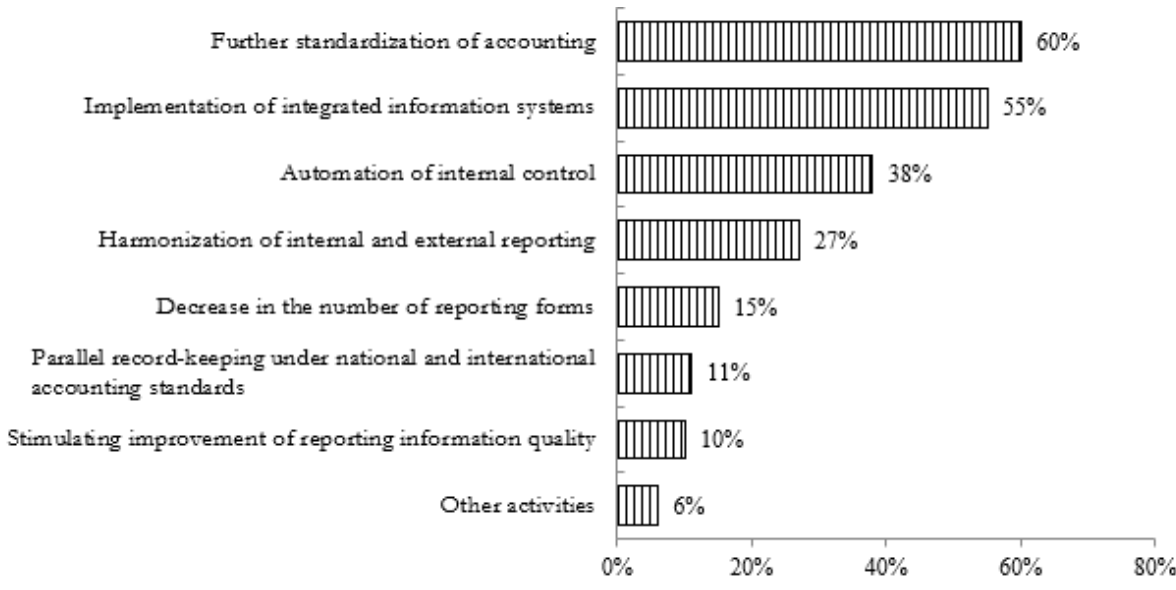

Figure 1. Activities that enterprises are willing to implement to improve the quality of financial reporting

Source: Authors' compilation using information from the official site of PwC (2016) 
In view of the above, we can state that today companies are interested in the formation of financial statements with high quality characteristics of the information presented in it, which allows to ensure a high level of confidence in them by users and will have a positive impact on the development of business. The quality of financial reporting correlates with the efficiency of the entire management process: the higher the qualitative characteristics of the information provided, the better the ability of managers to prepare optimal management decisions. Therefore, the problem of forming accounting information with high quality characteristics, which would meet the needs of various groups of users and increase their confidence in the accounting system, is on the agenda.

In the international standard ISO 9001: 2015 "The International Organization for Standardization, Quality Management Systems, 2015" the term "quality" means the degree to which the set of properties and characteristics of products or services meet the needs of consumers (The International Organization for Standardization 2015). In other words, when using the concept of "quality" means the extent to which a product, service or process meets the established requirements and criteria. Given that the information is an accounting product, it is correct to use the concept of "quality of accounting information" to determine the degree of compliance of the information presented in the financial statements to the needs of internal and external users. It is the assessment of financial statements that makes it possible to determine the degree of compliance of accounting information with the needs of users.

When assessing the quality of financial statements, it is necessary to take into account the peculiarities and principles of its formation, possible forms and formats of its presentation to users for decision-making. The basis of the methodology for assessing the quality of financial statements is a system of indicators, on the basis of which an overall assessment of the quality of accounting information in the financial statements of the enterprise is provided. At the same time, the assessment of the quality of financial statements should be carried out on the basis of accounting for qualitative and quantitative features that characterize various factors and circumstances of the formation and presentation of accounting information, existing users' requests in it, etc.

Since the quality of financial statements is determined by the characteristics of the information presented in it, it is necessary to evaluate it: 1) to determine the nomenclature of qualitative characteristics of financial statements; 2) to carry out quantitative measurement of qualitative characteristics of financial statements; 3) to compare the obtained results of assessment of quality of financial statements of one enterprise with similar characteristics of other enterprises or the standard of quality of financial statements. Conducting an assessment of the quality of financial reporting involves a series of sequential actions, grouped within the preparatory stage, the stage of quantitative assessment and the final stage (Figure 2). 


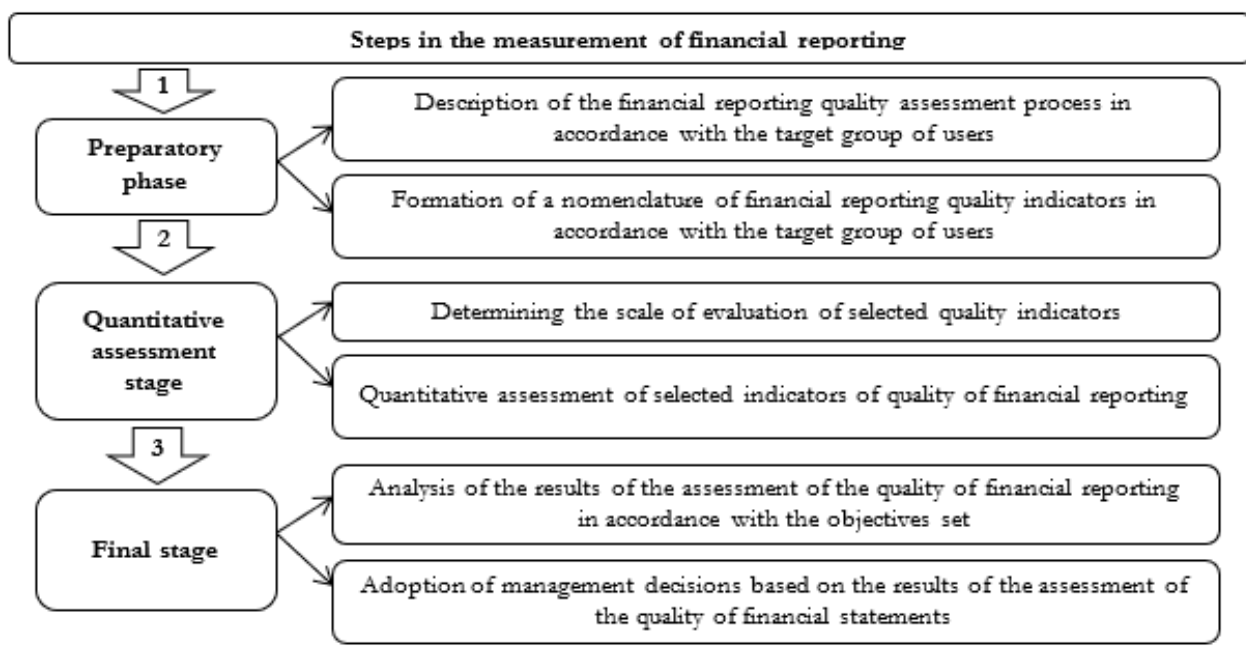

Figure 2. Stages of implementation of the methodology for evaluating the quality of financial reporting Source: development of the authors

The method of assessing the quality of financial statements at the preparatory stage shall include two main elements: identification of the group of objects to which the method is applied and identification of the group of users, taking into account the requirements of which it is developed. The main groups of users whose requirements should be taken into account when developing the methodology for assessing the quality of financial statements are internal users (enterprise management, corporate governance entities, employees) and external users (current and potential investors, creditors, auditors).

Before the direct assessment of the qualitative level of accounting information provided in the financial statements of the enterprise on the existing qualitative indicators, it is necessary to describe the assessment process taking into account the needs of various users of accounting information (Table 1).

Table 1. Description of the financial reporting assessment process

\begin{tabular}{|l|l|}
\hline $\begin{array}{l}\text { Stages of the assessment } \\
\text { process }\end{array}$ & Results of the evaluation process description \\
\hline $\begin{array}{l}\text { 1. Defining of homogeneous } \\
\text { groups of consumers of } \\
\text { financial reporting information }\end{array}$ & $\begin{array}{l}\text { Investors, lenders, enterprise management, corporate governance } \\
\text { entities, auditors }\end{array}$ \\
\hline $\begin{array}{l}\text { 2. Defining of a homogeneous } \\
\text { group of objects to be } \\
\text { evaluated, stages of their life } \\
\text { cycle }\end{array}$ & $\begin{array}{l}\text { Forms of financial statements (balance sheet (statement of } \\
\text { financial position), statement of financial performance (statement } \\
\text { of comprehensive income), statement of cash flows, statement of } \\
\text { equity) }\end{array}$ \\
\hline $\begin{array}{l}\text { 3. Determining the best } \\
\text { examples of financial } \\
\text { statements performs the same } \\
\text { functions as the financial } \\
\text { statements being evaluated }\end{array}$ & $\begin{array}{l}\text { Financial statements that fully comply with international } \\
\text { accounting standards and user requirements }\end{array}$ \\
\hline
\end{tabular}




\begin{tabular}{|l|l|l|}
\hline $\begin{array}{l}\text { Stages of the assessment } \\
\text { process }\end{array}$ & \multicolumn{2}{|l|}{ Results of the evaluation process description } \\
\hline $\begin{array}{l}\text { 4. Defining of evaluation } \\
\text { objectives for different user } \\
\text { groups }\end{array}$ & Investors & $\begin{array}{l}\text { Influence on investment decisions in the context } \\
\text { of: } \\
1 \text { ) determination of the volume of information } \\
\text { asymmetry between management and owners, } \\
\text { affecting the amount of costs incurred in the } \\
\text { selection of a promising investment project; } \\
\text { determination of the required level of costs of } \\
\text { external financing }\end{array}$ \\
\cline { 2 - 3 } & Lenders & $\begin{array}{l}\text { Impact on the creditworthiness assessment } \\
\text { process }\end{array}$ \\
\cline { 2 - 3 } & $\begin{array}{l}\text { Enterprise } \\
\text { management }\end{array}$ & $\begin{array}{l}\text { Influence on the level of adequacy of perception } \\
\text { of the economic reality of the enterprise, which } \\
\text { may lead to adjustments in management policy }\end{array}$ \\
\cline { 2 - 3 } & $\begin{array}{l}\text { Corporate } \\
\text { governance } \\
\text { entities }\end{array}$ & $\begin{array}{l}\text { Influencing the decisions of corporate } \\
\text { governance subjects in the context of identifying } \\
\text { information preferences between the } \\
\text { Corporation's managers and its principals }\end{array}$ \\
\cline { 2 - 3 } & $\begin{array}{l}\text { Impact on the audit process (sample size and } \\
\text { audit depth) }\end{array}$ \\
\hline
\end{tabular}

Source: compiled by the authors

Description of the process of assessment of financial statements is aimed primarily at determining the assessment objectives for each user group, i.e. at substantiating a set of decisions that may be made as a result of obtaining certain values of the indicator of comprehensive assessment of the quality of financial statements.

One of the main tasks of assessing the quality of financial reporting is the formation of qualitative indicators of accounting information in accordance with the needs of users, pre-defined tasks and objectives. Financial reporting of the enterprise, as an object of assessment, can be characterized on the basis of the use of a significant number of its properties, but in the process of assessing its quality should be used only those properties that ensure the satisfaction of the needs of users of accounting information (consumer properties). Such properties can be simple and complex. If simple properties are quite easy to measure with the use of single indicators, then complex properties are measured on the basis of combining simple properties, in general allow to calculate a complex indicator of quality of financial reporting.

The overall structure of the properties of financial statements is called the properties tree. In order to build it, a more detailed list of requirements for users of accounting information should be developed using the following sources:

- legislative requirements governing the formation and presentation of financial statements;

- internal regulatory requirements regarding the use of financial statements by entities, information is used to make decisions;

- Instructions on the use of other types of information for making similar decisions based on financial statements (management reporting, marketing information);

- internal normative requirements regulating the processes of formation of accounting 
information at the enterprise;

- results of studying the market of users of accounting information (stock markets, debt capital markets, etc.);

- forecast data related to expected user requirements (as a rule, published in official publications of subjects of accounting systems regulation or professional accounting organizations);

- Interviews with major groups of users of accounting information, etc.

Since all the above sources were taken into account by FASB and GAAP US when developing the classification of qualitative characteristics of financial information presented in the converged conceptual framework, and taking into account our suggestions for its improvement, the tree of properties of financial statements can be presented as follows (Figure 3).

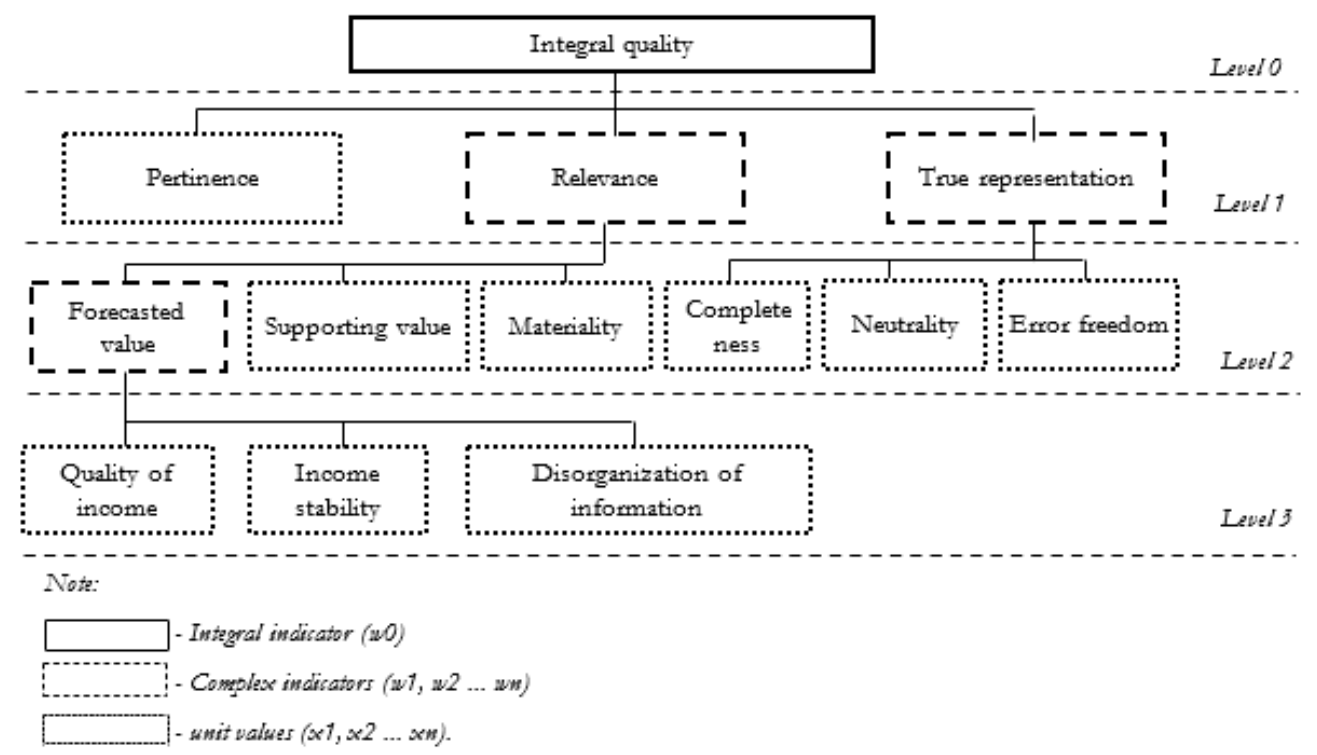

Figure 3. Tree of properties of financial statements

Source: compiled by the authors

The construction of the property tree of financial statements is important because if the transactions based on it are performed incorrectly, the results of assessment of the quality of financial statements may turn out to be erroneous.

First of all, unit indicators are formed on the basis of taking into account those properties of financial statements that can be used during the stage of quantitative assessment of its qualitative level, and as a result of their grouping, complex indicators are singled out.

The tree of properties can be supplemented with more detailed unit indicators at the level of a particular enterprise, if there is a possibility for their accurate calculation and it does not contradict the general rules of construction of classifications (the absence of intersection of properties that are evaluated by indicators, the hierarchy of the construction of the classification, the essence of the indicators in relation to their impact on complex 
indicators).

At the stage of quantitative assessment of the quality of financial statements, calculations of the pre-defined properties of financial statements are carried out directly. Performance of procedures at the stage of quantitative assessment of the quality of financial statements provides for the development of measurement scales for single indicators, the determination of the weighting coefficients of the quality of financial statements, the definition of reference values of the indicators of the properties of financial statements.

To calculate the different types of unit indicators, gradations are used, as they allow to divide all indicators into qualitative (gradations are determined by words) and quantitative (gradations are determined in numerical form). The totality of the gradations exhausts all possible manifestations of the financial reporting quality indicator to form a scale of its measurement.

Calculation of complex indicators is carried out on the basis of the use of a complex method that provides for the use of a single generalizing indicator, which combines a set of indicators, chosen to assess the quality of financial reporting. For this purpose, single indicators or complex indicators of the quality of financial reporting of the lower level are listed in the dimensionless indicators and taking into account the coefficients of their significance, the general complex or generalizing integral quality indicator is determined. At each of the selected levels of the tree of properties of financial reporting (level 1-3) (Figure 3) it is necessary to assess the relative importance of single and complex indicators, for which different types of methods based on the opinions of experts are used. It should be taken into account that the sum of weighting coefficients should always be equal to one and should be adhered to at all hierarchical levels of the tree of properties of financial reporting.

Based on the above, the general formula for calculating the integrated financial reporting quality indicator can be presented as follows:

$I Q A F F R=m_{1} P C+m_{2} R C+m_{3} T P R$

where the $I Q A F F R$ is the integral quality assessment factor for financial reporting;

$m_{1}, m_{2}, m_{3}$ - weighting coefficients of the IQAFFR components;

$P C$ - pertinence coefficient;

$R C$ - relevance coefficient;

TPR - True Presentation Ratio.

Relevance coefficient, based on the structure of the tree of properties of financial statements, is calculated as follows:

$R C=m_{1 r c} C P V+m_{2 r c} L S V+m_{3 r c} M L$

where, $R C$ is the relevance coefficient;

$m_{1 r c}, m_{2 r c}, m_{3 r c}$ - weight coefficients of the RC components;

$C P V$ - coefficient of prognostic value;

$L S V$ - level of supporting value;

$M L$ - materiality level.

The Projected Value Index is also a complex indicator, which is proposed to be calculated as follows: $C F V=m_{1 c f v} P Q R+m_{2 c f v} I S C+m_{3 c f v} I D C$

where, $C F V$ is the coefficient of forecast value;

$m_{1 c f v}, m_{2 c f v}, m_{3 c f v}$ - weight coefficients of the CFV components; 
$P Q R$ - profit quality ratio;

$I S C$ - income stability coefficient;

IDC - information disaggregation coefficient.

True presentation factor, based on the structure of the tree of properties of financial statements, is calculated as follows:

$T P F=m_{1 t p f} C F+m_{2 t p f} L N+m_{3 t p f} C F E$

where, TPF - True Presentation Factor;

$m_{1 t p f}, m_{2 t p f}, m_{3 t p f}$ - weight coefficients of the TPF components;

$C F$ - Completeness factor;

$L N$ - level of neutrality;

CFE - coefficient of freedom from errors.

The general characteristic and the order of calculation of the unit indicators used for calculation of the integral indicator of quality of the financial reporting are resulted in Table 2.

Table 2. Characteristics of single indicators used to calculate the integrated financial reporting quality indicator

\begin{tabular}{|c|c|c|c|}
\hline Indicator name & Formula & $\begin{array}{c}\text { Reference } \\
\text { value }\end{array}$ & Index content \\
\hline $\begin{array}{l}\text { Pertinence } \\
\text { Coefficient }\end{array}$ & $\begin{array}{l}\text { PC = ICFR / INU, } \\
\text { ICFR - Information capabilities of } \\
\text { financial reporting; } \\
\text { INU - information needs of users }\end{array}$ & 1 & $\begin{array}{l}\text { Characterizes the degree to which } \\
\text { financial reporting meets the } \\
\text { information needs of users }\end{array}$ \\
\hline $\begin{array}{l}\text { Profit Quality } \\
\text { Coefficient }\end{array}$ & $\begin{array}{l}\mathrm{PQC}=\left(\mathrm{NI}_{\mathrm{t}}-\mathrm{NI}_{\mathrm{t}-1}\right) / \mathrm{MV}_{\mathrm{t}-2} \\
\mathrm{NI}_{\mathrm{t}} \text { - net income for the period } \mathrm{t} \\
\mathrm{MV} \text { - market value at the end of the } \\
\text { reporting period } \mathrm{t}\end{array}$ & 1 & $\begin{array}{l}\text { Reflects the ability of an enterprise to } \\
\text { influence performance based on the } \\
\text { concept of "revenue management" }\end{array}$ \\
\hline \begin{tabular}{|l|} 
Income \\
Sustainability \\
Coefficient
\end{tabular} & $\begin{array}{l}\text { ISC = } 1 \text { - VOO / VFI, } \\
\text { VOO - volumes of one-off / } \\
\text { of unstable income; } \\
\text { VFI - volume of fixed income } \\
\end{array}$ & 1 & $\begin{array}{l}\text { Reflects the ability of an enterprise to } \\
\text { generate future revenues in the current } \\
\text { financial condition and performance }\end{array}$ \\
\hline $\begin{array}{l}\text { Disaggregation of } \\
\text { Information } \\
\text { Coefficient }\end{array}$ & $\begin{array}{l}\text { DIC = ORUI / ORFS, } \\
\text { ORUI - opportunities and risks of } \\
\text { the company's activity, discovered } \\
\text { on the basis of unaccounted } \\
\text { information; } \\
\text { ORFS - opportunities and risks of } \\
\text { the company's activity detected on } \\
\text { the basis of financial statements }\end{array}$ & 1 & $\begin{array}{l}\text { Characterizes the ability to identify } \\
\text { and assess the opportunities and risks } \\
\text { of the enterprise through the use of } \\
\text { financial statements }\end{array}$ \\
\hline $\begin{array}{l}\text { Supporting Value } \\
\text { Level }\end{array}$ & \begin{tabular}{|l|} 
SVL $=$ DRU $/ 100 \%$, \\
DRU - degree of response of users \\
to the published financial \\
statements, $\%$ (expertly determined) \\
\end{tabular} & 1 & $\begin{array}{l}\text { Characterizes the existence of user } \\
\text { reactions to (confirmation or change } \\
\text { in) preliminary estimates }\end{array}$ \\
\hline Materiality Level & $\begin{array}{l}\text { ML = DI / } 100 \% \text {, } \\
\text { DI - the degree of influence of } \\
\text { missing or incorrectly submitted } \\
\text { information in the financial } \\
\text { statements on decisions made by } \\
\text { users, \% (determined by expert } \\
\text { opinion) }\end{array}$ & 1 & $\begin{array}{l}\text { Characterizes the extent to which } \\
\text { information not available in the } \\
\text { financial statements influences } \\
\text { decisions made by users based on } \\
\text { financial information about a } \\
\text { particular business entity }\end{array}$ \\
\hline
\end{tabular}




\begin{tabular}{|l|l|c|l|}
\hline Indicator name & Formula & $\begin{array}{c}\text { Reference } \\
\text { value }\end{array}$ & Index content \\
\hline $\begin{array}{l}\text { Completeness } \\
\text { Factor }\end{array}$ & $\begin{array}{l}\text { CF = NPP / NEC, } \\
\text { NPP - the number of phenomena } \\
\text { and processes described are } \\
\text { disclosed in the financial } \\
\text { statements; } \\
\text { NEC - the number of event and } \\
\text { process characteristics required by } \\
\text { users to make decisions }\end{array}$ & $\begin{array}{l}\text { Reflects the extent to which the } \\
\text { characteristics of the phenomena and } \\
\text { processes are covered, and are } \\
\text { disclosed in the financial statements in } \\
\text { relation to user needs }\end{array}$ \\
\hline Neutrality Level & $\begin{array}{l}\text { NL } \text { DIS / 100\%, } \\
\text { DIS - the degree of impartiality of } \\
\text { the subjects of record keeping in } \\
\text { the selection or presentation of } \\
\text { financial information, \% } \\
\text { (determined by experts) }\end{array}$ & 1 & $\begin{array}{l}\text { Describes the degree of impartiality of } \\
\text { record-keeping entities in the selection } \\
\text { or presentation of financial } \\
\text { information }\end{array}$ \\
\hline $\begin{array}{l}\text { Error Freedom } \\
\text { Coefficient }\end{array}$ & $\begin{array}{l}\text { EFC = 1 - NFS / NCS, } \\
\text { NFS - the number of false } \\
\text { selection procedures and the } \\
\text { application of an appropriate } \\
\text { assessment process; } \\
\text { NCS - number of correct selection } \\
\text { procedures and application of the } \\
\text { appropriate assessment process. }\end{array}$ & 1 & $\begin{array}{l}\text { Characterizes the level of error-free } \\
\text { selection and the application of an } \\
\text { appropriate assessment process }\end{array}$ \\
\hline
\end{tabular}

Source: compiled by the authors

In order to evaluate the properties of the financial statements as defined in Fig. 3, other absolute or relative measures may be used that provide a more objective measure of the individual properties at the entity level. At the same time, all single indicators expressed in absolute values, which will be used to calculate the integral indicator of quality of financial reporting, should be translated at the same scale and expressed in the same units of measurement. In particular, they should be converted to relative indicators by means of the normalization operation, which stipulates that the interval of 0 VPp 1 reflects the linear relationship between the relative indicator function and the argument of the absolute indicator. Thus, all unit indicators, when used to calculate complex indicators, if necessary, should be converted to relative indicators, the values of which should be in the range of 0 to 1.

Based on the proposed approach to assessing the quality of financial reporting, it is possible to calculate different types of integral indicators for different groups of users of accounting information. The order of calculation of such integral indicators will differ in the application of different values of weights at different stages of determining integral indicators, the differences in which arise due to the existence of their different priorities in the process of meeting the needs of different types of users of accounting information. Benchmarks for financial reporting should be defined for comparison with the result of the assessment. An idea of the quality of financial reporting of a particular enterprise can be obtained only in relation to the original sample, in the absolute sense it can be higher or lower than this reference level. The choice of the reference model of the qualitative level of financial reporting depends on the objectives of the subjects, will make decisions based on the results of the assessment. 
Since the complex indicator of quality of financial reporting is calculated on the basis of complex and unit indicators at the enterprise level, the indicators of quality of the standard - basic indicators of quality - can also be developed. They can be used to assess the quality of individual areas of the accounting process or accounting departments responsible for compliance with a particular indicator.

One of the problems in the formation of a reference value for financial reporting quality indicators is the use of an algorithm for implementing such a value. Today, there are three most common approaches, which are described by researchers in the field of qualifications and used in practice. According to the first approach, it is necessary to choose several analogues of financial statements of other companies or statements of other periods of the given enterprise, among which it is necessary to choose the best one, proceeding from its qualitative characteristics. All quality indicators of the selected option of financial reporting are accepted as reference values with which to compare actual values. According to the second approach, among the established similar variants of financial reporting the best indicators of each of the properties are selected, which are accepted as reference values. According to the third approach, the best values of indicators of quality of financial reporting among analogues which are available in the world at the moment of quality assessment or established by the subjects of regulation of national or international accounting system are selected by reference values. The third approach is supported by representatives of the theoretical qualimetry, and its application does not lead to significant errors in the final results, compared to the first and second approaches, are the main reasons that make it advisable to use it in the process of forming a methodology for assessing the quality of financial reporting.

The final stage of assessment of the quality of financial reporting provides for the need to perform a number of procedures. Analysis of the obtained results of the financial statements quality assessment in accordance with the set objectives implies comparison of the actual values of the financial statements quality indicators (single, complex, integral) with the basic (reference) indicators. As a result of such a comparison, general deviations of the integral indicator of the quality of financial reporting and deviations of the values of complex and unit indicators should be determined, which will allow to determine the "problem areas" of the formation and submission of financial reporting at the enterprise, are the main reasons for obtaining an appropriate level of quality.

When comparing actual and reference quality indicators, it should be taken into account that they should have the same dimension, and since quality is always relative and has a probabilistic nature, its value cannot be greater than one.

When comparing actual and benchmark quality indicators, it should be borne in mind that they should be the same dimension, and because quality is always relative and probabilistic, it cannot be more than one value. If the actual values of the different levels exceed the reference values in the following cases of quality assessment, the financial statements to be assessed should become the benchmark.

The deviations obtained as a result of comparison are the basis for management decisions aimed at improving the existing financial reporting quality management system of the enterprise or for making adjustments to the composition of the used methods of financial reporting quality assessment.

Conducting clarifications of the calculation procedure and content of the previous stages 
of quality assessment is carried out in order to obtain more reasonable results that will meet both the objectives of the subjects of assessment, and the changing demands and needs of users of information on the quality level of financial reporting.

There are two main reasons for this change: 1) changes in the external environment; 2) changes in the internal environment. Changes in the external environment include changes in the objectives of the subjects of assessment and the requests and needs of users of information on the qualitative level of financial reporting. As a result, the set of qualitative properties of financial reporting can be changed, and it implies the need for a radical transformation of the existing methods of assessing the quality of financial reporting. Changes in the internal environment include changes in the priority role of individual components of integral and complex indicators of financial reporting quality, manifested in: changes in the weights used to calculate the indicators of the highest level; changes in the procedure for calculating unitary indicators of financial reporting quality (for example, when using a new model for assessing the quality of profit). Changes in the internal environment require correction of certain elements of the existing methods of assessing the quality of financial statements, can be carried out at the level of the enterprise within the framework of formation of a new quality management strategy on it.

\section{Conclusions}

Lack of unity in understanding the essence of the quality of financial reporting is explained by the multivariant interpretation of the basic concept of "quality". However, a common feature of most definitions is the dominant communication approach, in which the quality of information presented in the financial statements of the enterprise is determined by the level of practical suitability, feasibility and effectiveness of its use in decision-making. At the same time, under the quality of accounting information it is necessary to consider a set of its qualitative characteristics and properties that exist objectively and do not depend on the value criteria and needs of stakeholders.

In order to determine the level of satisfaction of users of accounting information the method of assessment of the quality of financial reporting is proposed, which is based on the developments in the field of qualimetry - the science of quantitative assessment of quality, aimed at the development of general theoretical and methodological foundations and individual applied methods of quality assessment. The model of quality assessment of financial reporting based on the use of qualimetric tools is the result of interaction of four main components (components) - the properties of financial reporting (assessed object), the subject of assessment, the used algorithm of assessment and reference properties of financial reporting.

Conducting an assessment of the quality of financial reporting involves the implementation of three successive stages: the preparatory stage (description of the process of assessment of the quality of financial reporting, the formation of a nomenclature of indicators of the quality of financial reporting); the stage of quantitative assessment (determination of the scale of assessment of selected quality indicators, the quantitative assessment of selected indicators of the quality of financial reporting); the final stage (implementation of the analysis of the obtained results of assessment of the quality of financial reporting, the adoption of the management). 
Practical implementation of the developed methodology of assessment of financial reporting allows to calculate the value of the integral indicator of quality of financial reporting and compare it with reference values, indicators of other enterprises of the industry or competitors in order to determine the quality level of financial reporting of a particular enterprise. In addition, the proposed assessment model allows to calculate different values of the integral indicator of the quality of financial reporting depending on the needs of users of accounting information and the priority properties of financial reporting in accordance with the target groups of users.

\section{References}

Al-Dmour, A., Abbod, M., Al-Balqa, N. (2018). The impact of the quality of financial reporting on nonfinancial business performance and the role of organizations demographic' attributes (type, size and experience). Academy of Accounting and Financial Studies Journal, 22 (1), 1- 16. Retrieved from: https://bura.brunel.ac.uk/bitstream/2438/15768/1/Fulltext.pdf. Accessed 12/01/2021.

Beest, F., Braam, G., Boelens, S. (2009). Quality of Financial Reporting: measuring qualitative characteristics. Retrieved from: https://www.ru.nl/publish/pages/516298/nice_09108.pdf. Accessed 09/12/2020.

Call, A., Campbell, J., Dhaliwal, D., Moon, J. (2017). Employee quality and financial reporting outcomes. Journal of Accounting and Economics, 64 (1), 123-149. doi: https://doi.org/10.1016/j.jacceco.2017.06.003. Accessed 15/12/2020.

Kalyani, S., Mathur, N., Gupta, P. (2019) Does Corporate Governance Affect the Financial Performance and Quality of Financial Reporting of Companies? A Study on Selected Indian Companies. Business Governance and Society. 105-125. doi: https://doi.org/10.1007/978-3-319-94613-9_7.

Nobesa, W. Ch. \& Stadlerb, Ch. (2015). The qualitative characteristics of financial information, and managers' accounting decisions: evidence from IFRS policy changes. Retrieved from: https://eprints.lancs.ac.uk/id/eprint/73717/1/ABR_2014_0103_R3.pdf. doi: https://doi.org/10.1080/00014788.2015.1044495. Accessed 20/12/2020.

Offenhammer, C., \& Wiegard, M. (2017). Management Reporting: Mit höherer Informationsdichte und Qualität mehr bewegen. Retrieved from: https://www.horvath-partners.com/fileadmin/horvathpartners.com/assets/05_Media_Center/PDFs/WP-PDFs_fuer_MAT-

Download/WP_Reporting_DE_web_g.pdf. Accessed 11/01/2021.

Panitz, K., Sauer, A., Waschkowitz, C. (2010). Quality Management in Reporting. Controlling, 2, 531-537. Retrieved from: https://www.pwc.de/de/prozessoptimierung/assets/controlling_10-2010.pdf. Accessed 02/12/2020.

Paucan, I.-D. (2015). Measuring the effects of IFRS adoption on accounting quality: a review. Procedia Economics and Finance, 32, 580-587.

Picot, A. (1989). The production factor information in the corporate governance. Zeitschrift zur Interaktion zwischen Theorie und Praxis in Marketing und Distribution, 4, 3-9.

Plakhtiy, T. \& Pravdiuk, N. (2017). Necessity of Assessing the Quality of Financial Reporting. Accounting and Finance, 3(77), 52-58.

Plakhtiy, T.F. (2018). Development of the theory and methodology of accounting based on a qualitative approach. Zhytomyr: O.O.Yevenok.

Pokynchereda, V., Gudzenko, N., Nastenko, M. (2017). Human resource accounting in the system of valuebased business management. Investment Management and Financial Innovations, 14(2-2), 386-393. doi: http://dx.doi.org/10.21511/imfi.14(2-2).2017.10. Accessed 11/01/2021.

Pravdiuk, N. \& Pravdiuk, M. (2016). Quality of Accounting Information: Essence and Assessment Method. Accounting and Finance, 2(72), 57-64.

Pravdiuk, N.L., Pokynchereda, V.V., Pravdiuk, M.V. (2019). The human capital of an enterprise: theory and assessment methodology. Baltic Journal of Economic Studies, 5 (2), 176-183. doi: https://doi.org/10.30525/2256-0742/2019-5-2-176-183. Accessed 15/01/2021. 
The International Organization for Standardization. (2015). Quality management systems. Retrieved from: https://www.iso.org/obp/ui/\#iso:std:iso:9001:ed-5:v1:en.

The official site of PwC (2021). Retrieved from: https://www.pwc.de. 